\title{
Rheological behavior and comparative analysis of nutrient composition of milk from three different breeds of goats, cows, and buffalo
}

\author{
Shiv Kumar Jayant ${ }^{1 *}$, Yashmin Bano ${ }^{2}$, Narottam Das Agrawal ${ }^{2}$ and Yogendra Kumar Kushwah ${ }^{1}$ \\ ${ }^{1}$ ICAR-CIRG Makhdoom, Farah, Mathura, India \\ ${ }^{2}$ Jiwaji University Gwalior, India
}

\begin{abstract}
Milk is a considerable resource of products whose composition varies. Four components are dominant in quantitative terms: water, fat, protein and lactose; while the minor components are minerals, enzymes, vitamins, and dissolved gases. Exogenous nutrients supply in the human diet is required because of their biological significance for common life conservation. Milk is said to be the most unique and ideal class of food, because it meets the nutritional needs of the body better than any single food. This study to investigate the major constituents of milk obtained from three different breeds of cows, Goats and found in local area of village such as Farah reason. Proximate parameters - moisture, ash, crude protein and lipid were determined by AOAC methods and Rheological behavior such as viscosity analysis in milk sample and mineral element analysis by using ICPMS (Perkin Elmer) to determine calcium, phosphorus, sodium, potassium and magnesium respectively.
\end{abstract}

\section{Introduction}

Milk is a complex mixture of proteins, carbohydrates, vitamins, minerals and other constituents dispersed in water [1]. It is one of the oldest foods known to man [2]. On the basis of the protein content of milk, it is generally regarded as "nature's most nearly perfect food" owing to its rich protein profile containing more essential amino acids than any other natural food [3]. In addition, milk is an important source of minerals especially calcium, phosphorus, sodium, potassium, chloride, iodine, magnesium, and small amounts of iron. These mineral constituents, calcium and phosphorus constitute a larger fraction in milk which is needed for bone growth and the proper development of newborns baby [4]. In humans, breast milk provides all the energy and nearly all nutrients required for infant growth and development during the first 1 to 6 months of life, as well as various immunological factors and bioactive components [5]. However, in the absence of breastfeeding, cow, Goat and Buffalo milk is commonly used as a weaning substitute for infants [6] often processed into various dairy formulas. Due to its high nutritive value, cow, Goat and Buffalo milk is widely consumed by infants and adults alike to meet their basic nutritional needs. Cow, Goat and Buffalo milk is the most universal raw material for processing dairy products resulting in the broadest spectrum of manufactured dairy products [7]. In Nigeria, cattle (cow) provide more than $90 \%$ of the total animal milk output while goats and sheep provide less than $10 \%$ and are kept for production of meat, hides and skin [8]. One of the primary goals of the dairy industry has always been to improve the technological properties of milk, including its chemical composition. Milk processing suitability is significantly affected by the proportions of milk components. It has been shown that the quality of milk intended for consumption and processing varies subject to Cow, Goat and Buffalo [7,9]. Hence there is need to exploit the local and exotic breeds of Cow, Goat and Buffalo in India in order to ascertain the best nutritionally enriched milk producer.

\section{Materials and methods}

Milk sample collection from Local area in Farah and three different animals' cows, Goat and Buffalo with an average age were used for this research. Early morning fresh milk samples were collected from the Cow, Goat and Buffalo with separate containers using standard milking procedures. To avoid contamination, containers used for sample collection were sterilized by soaking in $10 \% \mathrm{HNO} 3$ for 24 hours; then in distilled water for another 24 hours after which they were rinsed with more distilled water and finally dried ready for sample collection. The collected samples were immediately packaged and transported for analysis.

\section{Proximate Analysis}

Proximate parameters determined using the AOAC method. Moisture, ash, crude protein, and crude lipid contents were determined by oven drying, furnace, micro Kjeldah, soxlet extraction methods respectively [10].

\section{Mineral analysis}

The samples for mineral analysis were digested as per the procedure described by Kolmer [11] with slight modification. Briefly, $0.2 \mathrm{~g}$ sample was mixed with $7 \mathrm{ml}$ of nitric acid (HNO3) and $1 \mathrm{ml}$ Hydrogen peroxide in $50 \mathrm{ml}$ digestion tube. These samples were then kept in

${ }^{\star}$ Correspondence to: Shiv Kumar Jayant, ICAR-CIRG Makhdoom, Farah, Mathura, India, E-mail: shivjayant7aug@gmail.com

Key words: goat, cow, buffalo, milk, viscosity

Received: January 19, 2018; Accepted: February 01, 2018; Published: February 05,2018 
microwave digestion system for $1 \mathrm{hr} 20 \mathrm{~min}$ at max temperature $185^{\circ} \mathrm{C}$ on a micro-digestion bench. After digestion sample transferred in to 50 $\mathrm{ml}$ tube and final volume was make upto $25 \mathrm{ml}$. The digested samples were then analyzed by ICPMS (PerkinElmer, USA) for calcium (Ca), phosphorous $(\mathrm{P})$, and magnesium $(\mathrm{Mg})$, Sodium $(\mathrm{Na})$ and Potassium (K) were estimated.

Statistical Analysis The data was analyzed using one-way analysis of variance (ANOVA) with SPSS 16.0 to examine the statistical significance of differences in the mean concentration of the proximate and mineral compositions of the Cow, Goat and Buffalo milk samples studied.

\section{Results and discussion}

The mean values (\%) of the proximate analysis of milk samples obtained from the four different breeds of cow Goat and Buffalo milk samples studies are presented in Table1. The analysis of variance showed that moisture, protein, ash and lipid content were not significantly ( $p>0.05$ ) different between the samples. However, from table1, the fat content differed significantly.

An analysis of the proximate composition of the Cow, Goat and Buffalo milk samples showed that the moisture values of milk sample $86.24 \%, 87.35 \%, 83.92 \%$, protein value of milk sample $3.55 \%, 4.09 \%$, $2.28 \%$, Fat values of milk sample $4.25 \%, 3.50 \%, 10.5 \%$ and ash value of $1.15 \%, 1.05 \%, 1.39 \%$ respectively (Table 1 ). High moisture content is directly proportional to high water activity which in turn supports microbial growth consequently decreasing the shelf life of the milk sample. Conversely, low moisture content, implies low water activity, which causes the reduction of microbial growth and consequently increasing the shelf life of milk sample [12].

\section{Viscosity and $\mathrm{pH}$ analysis}

An analysis of the viscosity and $\mathrm{pH}$ composition of the Goat, Cow, and Buffalo milk samples showed that the viscosity $1.35,1.55$, and 3.50 respectively and $\mathrm{pH}$ values of milk sample such as Gaot, Cow and Buffalo in 6.71, 6.25, and 6.62 respectively (Table 2).

\section{Mineral analysis}

The macro (Ca, Na K, Mg and) and micro (P) minerals in Goat $171.60,38.54,121.17,12.58,95.03$ respectively, cow milk macro $(\mathrm{Ca}$, $\mathrm{Na} \mathrm{K}, \mathrm{Mg}$ and) and micro (P) minerals 133.25, 41.29, 146.50, 11.35, 79.20 respectively and Buffalo milk samples macro (Ca, $\mathrm{Na} \mathrm{K}, \mathrm{Mg}$ and) and micro (P) minerals 165.37, 40.94, 81.47, 13.01, 119.70 respectively concentration determined (Table 3). The concentration of these elements reported as ppm on liquid (200ul) basis.

\section{Conclusion}

Comparison of the proximate analysis of milk samples from thee different breeds such as Goat, Cow, and Buffalo milk samples in local

Table 1. The composition of milk from different mammals such as goats, cow and buffalo in percent of milk composition

\begin{tabular}{|c|c|c|c|c|c|}
\hline S.No. & Breads & Moisture \% & Protein \% & Fat \% & Ash \% \\
\hline 1. & Goats & $86.24 \pm 2.09$ & $3.55 \pm 1.35$ & $4.25 \pm 1.21$ & $1.15 \pm 0.10$ \\
\hline 2. & Cow & $87.35 \pm 2.07$ & $4.09 \pm 1.07^{*}$ & $3.50 \pm 1.11$ & $1.05 \pm 0.18$ \\
\hline 3. & Buffalo & $83.92 \pm 2.21$ & $2.28 \pm 0.98$ & $10.50 \pm 1.82^{*}$ & $1.39 \pm 0.11^{*}$ \\
\hline
\end{tabular}

Results are mean \pm S.E. of four set of observation.

$* \mathrm{P}<0.05, * * \mathrm{P}<0.001, * * * \mathrm{P}<0.0001$ and ${ }^{\#} \mathrm{P}>0.05$
Table 2. Viscosity and $\mathrm{pH}$ of milk from different mammals such as goats, cow and buffalo

\begin{tabular}{|c|c|c|c|c|}
\hline & & \multicolumn{3}{|c|}{ Milk Bread } \\
\hline S.No. & Experiment & Goats & Cow & Buffalo \\
\hline 1. & Viscocity & $1.35 \pm 0.11$ & $1.55 \pm 0.15$ & $3.5 \pm .021^{*}$ \\
\hline 2. & $\mathrm{pH}$ & $6.71 \pm 1.21$ & $6.25 \pm 1.35$ & $6.62 \pm 1.01$ \\
\hline
\end{tabular}

Results are mean \pm S.E. of four set of observation

$* \mathrm{P}<0.05, * * \mathrm{P}<0.001,{ }^{* * *} \mathrm{P}<0.0001$ and $^{\#} \mathrm{P}>0.05$

Table 3. Mineral profile analysis in milk from different mammals such as goats, cow and buffalo

\begin{tabular}{|c|c|c|c|c|}
\hline & & \multicolumn{3}{|c|}{ Milk Bread } \\
\hline S.No. & Mineral & Goats & Cow & Buffalo \\
\hline 1. & $\mathrm{Ca}$ & $171.60 \pm 5.5^{*}$ & $133.25 \pm 4.6$ & $165.37 \pm 6.2$ \\
\hline 2. & $\mathrm{Na}$ & $38.54 \pm 2.21$ & $41.29 \pm 2.32$ & $40.94 \pm 4.5$ \\
\hline 3. & $\mathrm{~K}$ & $121.17 \pm 3.5^{*}$ & $146.50 \pm 3.39^{*}$ & $81.47 \pm 6.0$ \\
\hline 4. & $\mathrm{P}$ & $95.03 \pm 3.4$ & $79.20 \pm 3.32$ & $119.70 \pm 3.8^{*}$ \\
\hline 5. & $\mathrm{Mg}$ & $15.28 \pm 1.11$ & $11.35 \pm .46^{*}$ & $13.01 \pm 0.3$ \\
\hline
\end{tabular}

Results are mean \pm S.E. of four set of observation

$* \mathrm{P}<0.05, * * \mathrm{P}<0.001, * * * \mathrm{P}<0.0001$ and ${ }^{*} \mathrm{P}>0.05$

market and area. Milk is a best nutritional dairy product but today largest market in India. Hence, different breeding such as Goat, Cow, and Buffalo, dairy breeds holds a great potential for the dairy industry.

\section{Acknowledgments}

These study data have not been presented any previously studies and conference. SKJ perform the experiments, collected the data, analyzed the data and wrote the article. NDG conceptualized the study, analyzed and discussed the data of the article.

\section{Conflict of interest}

The authors declare no conflict of interest.

\section{Funding}

There is no fund available in our institute and our department.

\section{References}

1. Harding F (1999) Milk quality. A Chapman and Hall Food Science Book. 1st Edition, Aspen publishers Inc, Gaithersburg, Maryland. pp: 23-50.

2. Nickerson SC (1972) Milk production: factors affecting milk composition. In: Milk quality, Aspan, H.F. (Ed.) 1st Edition, Chapman and Hall, Glasgow, Scotland, UK, pp: 3-23.

3. Foley RC, Bath DL, Dickinson FN, Tuckers HA (1972) Dairy cattle: principles, practices, problems and profits. Lea and Febiger, Philadelphia, Pennsylvania, pp: 2-15

4. Al-Wabel NA (2008) Mineral Contents of Milk of Cattle, Camels, Goats and Sheep in the Central Region of Saudi Arabia. Asian J Biochem 3: 373-375.

5. Titi Y, Yumei Z, Yibing N, Lili Y, Defu M, et al. (2017) Effects of flour or flaxseed oil upon intra-abdominal adiposity in male rats subjected to early weaning. $J$ Aging Res Clin Practice 6: 149-152

6. El-Agamy EI (2007) The challenge of cow milk protein allergy. Small Rumin Res 68 64-72.

7. Barłowska J, Szwajkowska M, Litwinczuk Z, Krol J (2011) Nutritional Value and Technological Suitability of Milk from Various Animal Species Used for Dairy Production. Comprehensive Reviews in Food Science and Food Safety 10: 291-302.

8. Walshe MJ, Grinddle A, Neji C, Benchman M (1991) Dairy Development in SubSahara Africa. World Bank Tech African Tech Dept Ser, pp: 1-20.

9. Poulsen NA, Gustavsson F, Glantz M, Paulsson M, Larsen LB, et al. (2012) Comparative analysis of nutrient composition of milk form different breeds of cows. Dairy Sci 95: 6362-6371.

10. AOAC (2000) Association of Analytical Chemists. Official Methods of Analysis, pp: $1-24$. 
Jayant SK (2018) Rheological behavior and comparative analysis of nutrient composition of milk from three different breeds of goats, cows, and buffalo

11. Kolmer J, Spauding EH, Robinson HW (1951) Fifth ed. In: Approved laboratory techniques. Aplenton Century Gopts. Inc, New York.
12. Londhe G, Pal D, Narender Raju P (2012) Effect of packaging techniques on shelf life of brown peda, a milk-based confection. LWT - Food Science and Technology 47: 117-125.

Copyright: (C2018 Jayant SK. This is an open-access article distributed under the terms of the Creative Commons Attribution License, which permits unrestricted use, distribution, and reproduction in any medium, provided the original author and source are credited. 